\title{
PENGARUH PESAN IKLAN, KETERLIBATAN IKLAN, KREDIBILITAS, DAN KECOCOKAN ENDORSER PADA MINAT BELI MELALUI SIKAP KONSUMEN
}

\author{
Peter Wijaya \\ Universitas Katolik Indonesia Atma Jaya Jakarta \\ e-mail: peter8wijaya@yahoo.com
}

\begin{abstract}
Abstrak
Penelitian ini bertujuan untuk mengetahui pengaruh pesan iklan, keterlibatan iklan, kredibilitas endorser, dan kecocokan endorser pada sikap terhadap iklan dan sikap terhadap merek Pharmaton ${ }^{\circledR}$ Formula. Selain itu, penelitian ini juga dilakukan untuk melihat pengaruh sikap terhadap iklan dan sikap terhadap merek pada minat beli produk Pharmaton ${ }^{\circledR}$ Formula. Untuk menguji variabel tersebut, penulis menggunakan iklan televisi Pharmaton ${ }^{\circledR}$ Formula dengan endorser selebritas Oka Antara. Penelitian dilakukan menggunakan metode multistage random sampling dengan 410 pekerja berusia $23-45$ tahun. Pengacakan pertama dilakukan untuk menentukan salah satu dari lima wilayah di Jakarta. Selanjutnya, dilakukan pengacakan kedua untuk menentukan mal yang akan dipilih sebagai tempat melakukan sampling. Selanjutnya, pengacakan ketiga adalah untuk menentukan hari dan waktu sampling agar setiap sampling dilakukan pada hari dan waktu yang berbeda. Hasil penelitian menunjukkan bahwa pesan iklan, keterlibatan iklan, kredibilitas endorser, dan kecocokan endorser memberikan pengaruh positif pada sikap terhadap iklan dan sikap terhadap merek Pharmaton ${ }^{\circledR}$ Formula. Sikap terhadap iklan memberikan pengaruh positif pada sikap terhadap merek Pharmaton ${ }^{\circledR}$ Formula. Sikap terhadap iklan dan sikap terhadap merek juga memberikan pengaruh positif pada minat beli produk Pharmaton ${ }^{\circledR}$ Formula.
\end{abstract}

Kata kunci: pesan, keterlibatan, kredibilitas endorser, kecocokan, sikap terhadap iklan, sikap terhadap merek, minat beli

\begin{abstract}
This study aimed to determine the effect of advertising messages, advertising involvement, endorser credibility and endorser congruency on attitude toward advertisement and attitude toward brand Pharmaton ${ }^{\circledR}$ Formula. In addition, this study was also conducted to see the effect of attitude toward advertisement and attitude toward brand to purchase intention of Pharmaton ${ }^{\circledR}$ Formula.To test these variables, the authors use television advertising Pharmaton ${ }^{\circledR}$ Formula with Oka Antara as the celebrity endorser. The study was conducted using a multistage random sampling method with 410 workers aged 23-45 years. Randomization was first performed to determine one of five areas in Jakarta. Subsequently, a second randomization is to determine the mall that will be chosen as sampling place. Furthermore, the third randomization is to determine the day and time of sampling so that each sampling carried out on different days and times. The results showed that advertising messages, advertising involvement, endorser credibility and endorser congruency have a positive influence on attitude toward advertisement and attitude toward brand Pharmaton ${ }^{\circledR}$ Formula. Attitude toward advertisement have a positive influence to attitude toward brand Pharmaton ${ }^{\circledR}$ Formula. Attitude toward advertisement and attitude toward brand also have a positive influence on purchase intention of Pharmaton ${ }^{\circledR}$ Formula.
\end{abstract}

Keywords: messages, endorser credibility, congruency, attitude towards advertisement, attitude towards brand, purchase intention 


\section{PENDAHULUAN}

Industri farmasi di Indonesia, terutama dalam produk obat OTC (over-the-counter) atau obat yang dapat dibeli tanpa resep dokter serta produk multivitamin, masih terus tumbuh dan berkembang dalam beberapa tahun terakhir. Berdasarkan informasi yang diulas dalam artikel "Segmen Menengah dan Bawah Dorong Industri Farmasi" yang tertera dalam http://www.marketing.co.id/, dilaporkan bahwa pasar produk OTC di Indonesia tumbuh $10 \%$ hingga Agustus 2013 atau meningkat dua kali lipat jika dibandingkan periode yang sama tahun lalu. Menurut survei Nielsen tahun 2013 yang disadur dalam artikel tersebut, penjualan produk OTC atau obat tanpa resep dokter ini terutama didorong oleh konsumen kelas menengah dan bawah.

Pada konsumen kelas menengah, hingga Agustus 2013, pengeluaran rumah tangga untuk produk farmasi OTC terjadi di semua segmen, dan vitamin merupakan segmen yang penetrasinya lebih tinggi di setiap rumah tangga sebesar $56 \%$. Pengeluaran tertinggi kedua adalah obat batuk 22\%, disusul obat analgesik dan penurun demam $21 \%$. Pada konsumen kelas bawah, semua segmen produk farmasi OTC mengalami kenaikan yang signifikan akibat terjadi peningkatan nilai pembelanjaan. Di kelas ini, seperti halnya pada konsumen kelas menengah, segmen vitamin bertumbuh 56\%. Sementara itu, segmen obat analgesik dan penurun demam bertumbuh sebesar $43 \%$, dan segmen obat batuk bertumbuh sebesar $27 \%$ (http://www.marketing.co.id/).

Suatu survei yang dilakukan Nielsen dengan judul "Global AdView Pulse" mengenai tren periklanan global untuk kuartal tiga tahun 2013, menunjukkan data pembelian iklan hingga kuartal ketiga tahun 2013 yang memperlihatkan tingkat pembelanjaan untuk iklan dalam industri kesehatan (termasuk industri farmasi) berada di peringkat ketiga setelah industri otomotif (peringkat pertama) dan industri media dan penerbitan (peringkat kedua).

Dalam penerapan strategi pemasaran, strategi positioning dan komunikasi yang efektif menjadi hal yang penting untuk mencapai kesuksesan sebuah merek, terutama saat menghadapi lingkungan pemasaran yang kompetitif (Khatri, 2006). Iklan dianggap sebagai cara paling efisien untuk menyampaikan informasi produk kepada konsumen. Kalimat dan gambar sering digunakan untuk mendeskripsikan suatu produk serta menarik perhatian konsumen. Dari semua jenis penyampaian pesan (endorsement), biasanya pembawa pesan (endorser) selebritas umum digunakan oleh pemasar dengan tujuan untuk meningkatkan minat beli konsumen. Selain berpengaruh pada minat beli, dukungan dari selebritas dalam sebuah iklan juga dapat mempengaruhi citra merek suatu produk (Wang, 2013).

Pharmaton ${ }^{\circledR}$ Formula, salah satu merek multivitamin mineral yang dipasarkan oleh PT Boehringer Ingelheim Indonesia di bawah unit bisnis Consumer Health Care (CHC, yang fokus pada produk OTC dan multivitamin), termasuk ke dalam produk yang kerap diiklankan. Pada awal tahun 2013, sebuah iklan baru untuk produk Pharmaton ${ }^{\circledR}$ Formula telah diluncurkan dengan menampilkan pesan yang baru disertai simbol baterai. Penggunaan simbol baterai dalam iklan baru ini dirancang agar iklan tersebut memiliki daya tarik dibandingkan dengan iklan multivitamin lainnya. Selain itu, iklan Pharmaton ${ }^{\circledR}$ Formula yang ditayangkan hingga kuartal kedua tahun 2014 ini juga menggunakan figur selebritas, yaitu Oka Antara.

Pada kasus Pharmaton ${ }^{\circledR}$ Formula, penggunaan endorser selebritas (Oka Antara) justru tidak memperlihatkan dampak positif terhadap tingkat penjualan (atau market share) Pharmaton ${ }^{\circledR}$. Di tahun 2012, Pharmaton ${ }^{\circledR}$ berhasil meraih market share sebesar $6,7 \%$. Setelah meluncurkan iklan barunya di tahun 2013, hal yang terjadi adalah justru market share Pharmaton $^{\circledR}$ menurun ke angka $6,4 \%$. Fenomena ini justru tidak sesuai dengan teori yang menyatakan bahwa penggunaan endorser selebritas dapat memberikan pengaruh positif terhadap minat beli konsumen dan pada akhirnya terhadap tingkat penjualan (atau market share) suatu produk. Di awal penggunaan iklan Pharmaton $^{\circledR}$ Formula versi Oka Antara (kuartal pertama tahun 2013), justru penjualan Pharmaton $^{\circledR}$ sempat mengalami penurunan sebelum akhirnya kembali menaik di kuartal kedua tahun 2013. Kenaikan di kuartal kedua tahun 2013 tersebut diikuti dengan tren penurunan penjualan hingga kuartal keempat tahun 2013. Walaupun penjualan Pharmaton ${ }^{\circledR}$ sempat kembali menaik di kuartal pertama tahun 2014, 
penjualan di kuartal kedua tahun 2014 kembali menurun. Berdasarkan fenomena tersebut, menjadi hal yang menarik untuk membahas mengenai pengaruh endorser selebritas pada minat beli konsumen produk multivitamin mineral, khususnya Pharmaton ${ }^{\circledR}$ Formula.

Suatu studi pendahuluan (pra-survei) telah dilakukan peneliti terhadap 50 responden di Jakarta untuk memperlihatkan secara jelas fenomena yang terjadi sesungguhnya. Pertanyaan pertama dalam studi pendahuluan ini ingin melihat tingkat kesadaran responden terhadap merek Pharmaton ${ }^{\circledR}$ Formula secara umum. Hasil yang diperoleh menunjukkan bahwa hampir seluruh responden (90\%) mengetahui merek Pharmaton ${ }^{\circledR}$ Formula.

Pertanyaan selanjutnya menanyakan mengenai tingkat kesadaran responden terhadap iklan Pharmaton ${ }^{\circledR}$ Formula. Ternyata, sekitar 3 dari 5 responden mengetahui dan pernah melihat iklan Pharmaton ${ }^{\circledR}$ Formula. Hal ini menunjukkan bahwa sebenarnya responden sudah mengetahui merek dan sadar akan adanya iklan Pharmaton ${ }^{\circledR}$ Formula.

Kemudian, pertanyaan berikutnya diajukan kepada responden untuk melihat hubungan antara iklan dan minat beli responden terhadap produk Pharmaton ${ }^{\circledR}$ Formula. Hasil yang diperoleh menunjukkan bahwa ternyata hanya sebagai kecil (sekitar 3 dari 10) responden yang menganggap iklan mempengaruhi minat untuk membeli Pharmaton ${ }^{\circledR}$ Formula.

Pertanyaan terakhir yang diajukan kepada responden dalam studi pendahuluan ini adalah mengenai faktor yang mempengaruhi minat beli produk multivitamin mineral secara umum. Responden diminta untuk memilih 3 dari 7 faktor yang tersedia dengan urutan dimulai dari faktor yang dinilai paling mempengaruhi minat beli mereka terhadap produk multivitamin mineral secara umum. Hasil yang diperoleh memperlihatkan ternyata sekitar $68 \%$ responden menilai pengalaman sebelumnya terhadap multivitamin mineral sebagai faktor yang mempengaruhi minat beli terhadap produk tersebut. Hasil tersebut diikuti dengan faktor harga $(60 \%)$, rekomendasi keluarga $(56 \%)$, rekomendasi teman (44\%), iklan produk $(30 \%)$, rekomendasi apoteker/dokter (28\%), dan promosi dalam toko/apotek (14\%). Hal tersebut menunjukkan bahwa responden yang sudah pernah mengonsumsi suatu produk multivitamin mineral akan cenderung untuk membeli produk yang sama. Iklan produk menjadi faktor kelima yang dianggap dapat mempengaruhi minat beli produk multivitamin mineral.

Jika dilihat dari faktor utama yang paling mempengaruhi minat beli produk multivitamin mineral, rekomendasi teman (32\%) dan rekomendasi keluarga (30\%) menempati urutan teratas sebagai faktor yang mempengaruhi minat beli. Faktor iklan (10\%) berada sejajar dengan harga $(10 \%)$ dalam mempengaruhi minat untuk membeli produk multivitamin mineral, sedangkan pengalaman sebelumnya (14\%) juga menjadi faktor penentu sebagian responden untuk membeli produk multivitamin mineral.

Dari ulasan sebelumnya, terlihat adanya gap fenomena pada Pharmaton ${ }^{\circledR}$ Formula. Secara teoritis, iklan dan endorser dalam iklan akan memberikan pengaruh positif terhadap minat beli, secara tidak langsung pada tingkat penjualan. Namun, pada Pharmaton ${ }^{\circledR}$ Formula, penggunaan endorser (Oka Antara) tidak memperlihatkan fenomena yang sama dengan teori. Oleh karena itu, penulis ingin melakukan penelitian mengenai efektivitas iklan (termasuk penggunaan endorser selebritas) pada minat beli produk multivitamin mineral, khususnya dalam merek Pharmaton ${ }^{\circledR}$ Formula. Efektivitas iklan terlihat melalui sikap terhadap iklan, sikap terhadap merek, dan minat beli konsumen (Aziz et al, 2013). Faktor yang mempengaruhi efektivitas iklan yang diteliti oleh Hemamalini dan Kurup (2014) mencakup pesan iklan, (kredibilitas) endorser selebritas, dan keterlibatan iklan.

\section{KAJIAN PUSTAKA}

\section{Advertising Response Modeling (ARM)}

Advertising Response Modeling (ARM) menggambarkan kerangka untuk mengukur kinerja sebuah iklan melalui dua alternatif rute persuasi, yaitu proses sentral dan proses perifer (gambar 1). Proses sentral lebih difokuskan pada variabel produk atau merek dan variabel pesan. Konsumen mempertimbangkan atribut produk dan manfaat yang ditawarkan dalam iklan. Proses perifer lebih difokuskan pada aspek kreativitas dalam pembuatan iklan seperti alur cerita, gambar, musik, dan endorser dalam iklan tersebut (Mehta, 1994). 


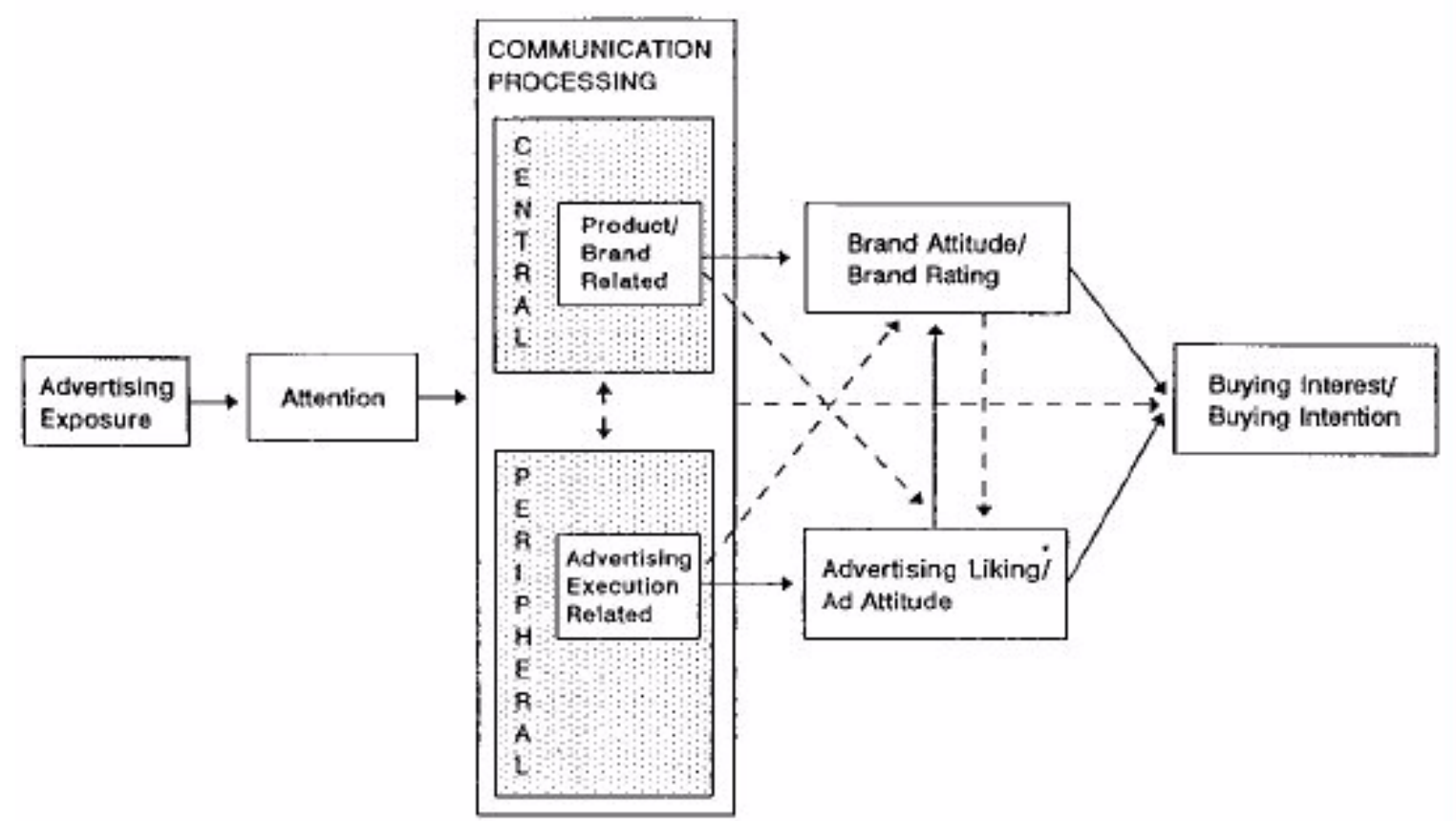

Gambar 1. Advertising Response Model (ARM).

Sumber: Mehta, 1994.

Sesuai dengan pendekatan proses perifer, tahapan respon konsumen mengikuti alur berikut. Iklan efektif akan menarik perhatian kemudian konsumen memproses informasi (dengan titik berat pada proses perifer), dan selanjutnya sikap positif atau negatif terhadap iklan muncul, hingga akhirnya menimbulkan minat beli. Persuasi melalui jalur proses perifer dilakukan dengan menekankan visualisasi gambar atau materi simbolik seperti musik, bintang iklan, dan lainnya.

Variabel yang diteliti dalam model penelitian ARM mencakup tiga hal, yaitu sikap terhadap iklan, sikap terhadap merek, dan minat pembelian.

\section{Pesan Iklan}

Saat ini konsumen dihadapkan dengan banyak pesan iklan dari berbagai sumber dan media komunikasi. Pesan iklan dan penempatan pesan dalam iklan menjadi salah satu hal yang mempengaruhi penilaian dan keputusan konsumen terhadap suatu produk. Pesan iklan terbukti memberikan hubungan signifikan terhadap efektivitas iklan dalam hal minat beli (Buda dan Zhang, 2000). Penelitian yang mereka lakukan juga menunjukkan bahwa pesan iklan yang paling penting harus diletakkan di awal iklan untuk menarik minat dan meyakinkan konsumen terhadap produk yang diiklankan.

Hal yang menjadi fokus dalam pesan iklan adalah komunikasi dalam iklan tersebut apakah mengandung pesan yang mampu membedakan merek suatu produk dengan produk lainnya atau tidak. Beberapa hal lain yang menjadi pertimbangan pemasar dalam membuat sebuah pesan adalah presentasi pesan dalam bentuk kalimat atau gambar, frekuensi pengulangan pesan, penempatan kesimpulan secara langsung atau tidak langsung, penggunaan pesan yang mewakili semua pihak yang berbeda pendapat, serta perbandingan langsung atau tidak langsung dengan kompetitor produk (Solomon, 2008: 326).

\section{Kredibilitas Endorser}

Kredibilitas endorser adalah karakter positif dari seseorang (sender) yang dapat mempengaruhi penerima (receiver) dalam menerima pesan (Stafford et al, 2002). Kredibilitas sumber tergolong banyak digunakan dalam komunikasi iklan karena ditujukan untuk mengubah sikap konsumen sasaran/target mengenai produk atau merek yang diiklankan. Endorser/sumber tersebut diberikan kepercayaan oleh pihak perusahaan untuk menjadi pembawa pesan persuasif 
untuk mempengaruhi konsumen agar dapat menggunakan suatu produk.

Kredibilitas endorserdapat dilihat dari tiga dimensi, yaitu dimensi daya tarik (attractiveness), kepercayaan (trustworthiness), dan keahlian (expertise) (Ohanian, 1990). Ketiga dimensi ini masing-masing diukur melalui beberapa indikator dengan skala semantik diferensial. Dimensi daya tarik dijelaskan melalui lima indikator, yaitu menarik (attractive), berkelas (classy), tampan/ cantik (beautiful), elegan (elegant), dan seksi (sexy). Dimensi kepercayaan digambarkan oleh indikator dapat diandalkan (dependable), jujur (honest), tulus (sincere), dan dapat dipercaya (reliablel trustworthy). Dimensi keahlian diuraikan melalui lima indikator meliputi ahli (expert), berpengalaman (experienced), berpengetahuan (knowledgeable), berkualitas (qualified), dan terampil (skilled).

Lafferty dan Goldsmith (1999) menemukan bahwa endorser dengan kredibilitas tinggi lebih efisien daripada endorser dengan kredibilitas rendah dalam mempengaruhi sikap konsumen. Selebritasdiyakini memiliki daya pikat dari pada non-selebritas (Rex,1997). Selain itu, Mehta (1994) menunjukkan bahwa terdapat perbedaan respon koginitif pada penontonatas iklan yang menggunakan selebritas dan non-selebritas. Penonton iklan dengan selebritas cenderung memperhatikan selebritassnya, sedangkan penonton iklan nonselebritas cenderung memperhatikan detil produknya. Hal ini sejalan dengan Erdogan (1999) yang menyatakan bahwa kualitas selebritas tidak selalu tepat, relevan, dan seperti yang diinginkan oleh pemasar untuk menyampaikan suatu produk.Ishak (2008) dalam studinya juga menghasilkan kesimpulan bahwa daya pikat endorser tidak mempengaruhi sikap penonton terhadap iklan. Oleh karena itu, penggunaan endorser dalam sebuah iklan sangat penting untuk mempertimbangkan kredibilitas endorser terpilih karena menjadi salah satu faktor yang menguatkan audience untuk mempercayai kebenaran iklan tersebut (Goldsmith et al, 2000; Stephanie,2013).

\section{Kecocokan Endorser}

Kecocokan antara endorser dengan produk atau merek ("match-up hypothesis") yang dibawakan seringkali menjadi salah satu kunci efekti- vitas dari sebuah endorsement. Kecocokan atau kongruensi endorser mengacu pada tingkat kesesuaian citra diri seorang endorser dengan produk yang dibawakan (Biswas et al, 2006). Semakin tinggi kecocokan antara endorser dengan produk, yang dinilai oleh konsumen, semakin tinggi pula efektivitas dari endorsement (Friedman and Friedman, 1979).

Seorang endorser dikatakan memiliki kongruensi tinggi apabila endorser tersebut dipersepsikan memiliki kesesuaian (match-up) dengan produk yang diiklankannya. Sebaliknya, seorang endorser dikatakan memiliki kongruensi rendah apabila endorser tersebut dipersepsikan memiliki kesesuaian yang lemah dengan produk yang diiklankannya. Penelitian terdahulu menemukan bahwa endorser yang memiliki kesesuaian tinggi pada produk yang diiklankannya akan memiliki respon konsumen yang lebih positif (Biswas et al., 2006). Penelitian lainnya yang dilakukan oleh Choi and Rifon (2012) menunjukkan bahwa kecocokan (kongruensi) endorser dengan produk memberikan efek positif dan langsung pada sikap konsumen terhadap iklan, dan efek tidak langsung pada sikap terhadap merek dan minat beli konsumen.

\section{Keterlibatan Iklan}

Hemamalini dan Kurup (2014) menyampaikan bahwa keterlibatan selalu berkaitan dengan pertimbangan aktif suatu informasi atau ketertarikan tertentu terhadap suatu produk. Dalam penelitian tersebut, keterlibatan iklan memiliki hubungan dengan minat beli konsumen.

Penelitian lain yang dilakukan oleh Maheswaran and Meyers-Levy (1990) menunjukkan beberapa hasil. Saat keterlibatan iklan rendah, konsumen tidak memproses pesan sepenuhnya dan membuat penilaian berdasarkan sikap mereka sehingga pesan akan lebih persuasif jika ditampilkan dalam konteks positif. Jika keterlibatan iklan tinggi, konsumen akan memproses iklan secara detail dan membuat penilaian secara normatif dan sesuai respon yang tidak memihak. Untuk jenis keterlibatan tinggi, pesan akan lebih persuasif jika ditampilkan dalam konteks negatif.

\section{Sikap Terhadap Iklan}


Sikap terhadap iklan merupakan perwakilan respon konsumen yang menyenangkan atau tidak terhadap suatu iklan (Solomon, 2009: 287) dalam bentuk menguntungkan atau tidak meguntungkan dan baik atau tidak baik (Dominanto, 2008; Biehal et al, 1992) dalam suatu situasi eksposur tertentu (Biehal et al, 1992). Respon tersebut dihasilkan secara spesifik dari hal yang dilihat dan didengar, perasaan yang dimunculkan oleh iklan, dan derajat pengaruh terhadap minat psikologis. Perasaan konsumen terhadap konteks yang terlihat dalam iklan juga dapat mempengaruhi sikap terhadap merek. Efek sikap terhadap iklan ini menekankan bahwa iklan memiliki potensi penting dalam proses pembelian. Saat konsumen tidak melihat iklan kembali, kepercayaan terhadap suatu merek akan hilang dengan sendirinya, sehingga iklan perlu ditayangkan dengan frekuensi tertentu. Respon kognitif yang positif umumnya menghasilkan sikap positif konsumen terhadap iklan dan sebaliknya (Mehta, 1994).

\section{Sikap terhadap Merek}

Sikap terhadap merek merupakan evaluasi menyeluruh terhadap merek yang dilakukan oleh konsumen. Evaluasi tersebut tersaji dalam bentuk menguntungkan atau tidak meguntungkan dan baik atau tidak baik (Dominanto, 2008; Biehal et al, 1992) yang muncul setelah melihat iklan terhadap merek barang tersebut diiklankan (MacKenzie \& Lutz, 1989).Sikap terhadap merek tertentu sering mempengaruhi apakah konsumen akan membeli atau tidak. Sikap terhadap merek merupakan persepsi atau penilaian penerima pesan terhadap merek atau produk secara positif atau negatif, suka atau tidak suka, berkualitas atau tidak. Keyakinan ini muncul setelah target konsumen mengonfirmasi pesan dan informasi yang ditawarkan (Mehta, 1994).

\section{Minat Beli}

Niat (minat) berperilaku adalah mode yang paling baik untuk memprediksi perilaku individu (Biehal et al, 1992; Bosnjak et al, 2006). Dalam penelitian ini, minat berperilaku yang dimaksud adalah minat untuk membeli. Solomon (2009: 301) menyatakan bahwa minat beli tidak dapat dipisahkan dari teori keputusan pembelian konsumen, karena minat merupakan salah satu dari proses akhir keputusan pembelian dari konsumen. Minat atau niat untuk membeli merupakan rencana kognitif atau keinginan konsumen untuk membeli suatu barang atau merek tertentu. Secara umum, minat beli merupakan keinginan untuk membeli produk yang diiklankan setelah mendapatkan informasi dan pemaparan suatu iklan (Mehta, 1994).

\section{Penelitian Terdahulu}

Penelitian yang dilakukan Zafar and Rafique (2012) dengan judul "Impact of Celebrity Advertisement on Customers' Brand Perception and Purchase Intention" melibatkan 103 responden (pekerja) yang berada di Pakistan dengan lingkungan kerja di perusahaan pemerintah, swasta, dan multinasional. Pembahasan data menggunakan alat analisis SPSS. Penelitian ini membuktikan adanya hubungan antara physical attractiveness, source credibility, dan celebrity congruency terhadap sikap konsumen (terhadap iklan dan merek) serta terhadap minat beli.

Hasil yang diperoleh adalah celebrity endorsement (penyampaian pesan oleh selebritas) memiliki dampak terhadap sikap dan minat beli konsumen. Faktor selebritas tidak hanya menjadi faktor yang mempengaruhi, tetapi juga menjadi faktor kausal sesuai dengan hasil penelitian tersebut. Daya tarik fisik, kredibilitas, dan kongruensi atau kecocokan selebritas dalam iklan memberikan dampak terhadap persepsi konsumen mengenai produk yang disampaikan dalam iklan.

Saat ini, konsumen sudah sadar akan keberadaan dan pengaruh media. Selain itu, selebritas sudah dianggap sebagai sebuah ikon sehingga daya tarik fisik $($ Rex,1997)dan kredibilitas selebritas (Lafferty dan Goldsmith, 1999) serta kecocokan antara selebritas (Biswas et al., 2006) dengan produk yang diiklankan akan mempengaruhi konsumen untuk menyukai dan akhirnya membeli produk tersebut. Fitur atau keunggulan produk menjadi prioritas sekunder bagi konsumen.

Penelitian yang dilakukan Aziz et al (2013)memiliki tujuan untuk mengukur dampak kredibilitas dari seorang celebritas terhadap efektivitas iklan. Sampel yang dipilih untuk menjadi responden dalam studi ini sebanyak 145 mahasiswa MBA dari berbagai universitas dengan rentang usia 25 hingga 30 
tahun. Objek penelitian yang dipilih adalah minuman dingin dengan berbagai merek yang diiklankan dengan endorser selebritas atau bukan selebritas.

Efektivitas iklan diukur dalam tiga dimensi meliputi sikap terhadap iklan yang dihubungkan dengan sikap terhadap merek yang kemudian berkaitan dengan minat beli konsumen. Sementara itu, kredibilitas endorser diukur melalui tiga dimensi, yaitu kepercayaan (trustworthiness), daya tarik (attractiveness), dan keahlian (expertise). Hasil yang diperoleh dari penelitian ini adalah selebritas dengan kredibilitas yang tinggi memiliki pengaruh yang besar pada sikap konsumen terhadap iklan. Konsumen dengan sikap positif terhadap iklan memiliki sikap positif terhadap merek, dan akhirnya mengarah pada minat beli yang positif terhadap produk.

Iklan dengan endorser selebritas yang memiliki kredibilitas tinggi dapat mempengaruhi beberapa hal seperti meningkatkan reputasi korporasi secara umum, meningkatkan kepercayaan terhadap merek dan minat konsumen untuk membeli produk kembali, mengurangi sensitivitas harga, meningkatkan persepsi diferensiasi dengan produk lain, memudahkan konsumen untuk mengenal dan mengingat kembali merek sehingga merek dapat menduduki posisi top of mind.

Penelitian Hemamalini and Kurup (2014) melibatkan 50 responden mahasiswa, membahas mengenai efektivitas iklan televisi terhadap minat beli konsumen. Beberapa variabel yang diteliti dalam penelitian ini adalah penggunaan selebritas, strategi pesan, dan strategi keterlibatan iklan, serta minat beli.

Penelitian ini memperlihatkan hasil bahwa terdapat pengaruh antara keterlibatan iklan, pesan iklan, serta penggunaan selebritas dalam iklan televisi dengan minat beli konsumen terhadap produk yang diiklankan. Konsumen memiliki minat beli yang tinggi terhadap produk yang diiklankan dengan endorser selebritas yang cocok dengan produk tersebut, bukan sekedar tampil dalam iklan atau sebagai model iklan. Minat beli konsumen juga tinggi jika pesan iklan dianggap sebagai pesan yang terpercaya.

Wangsa dan Ardani (2015) melakukan penelitian mengenai niat beli yang dipengaruhi oleh kredibilitas Al Ghazali sebagai endorser pada iklan Men's Biore Cool Oil Clear. Hubungan tersebut juga menganalisis efek mediasi yang diberikan oleh variabel sikap terhadap iklan. Dengan melibatkan 100 responden di kota Denpasar, hasil penelitian ini menyatakan bahwa kredibilitas endorser berpengaruh positif pada sikap terhadap iklan dan niat beli. Sikap terhadap iklan juga terbukti memiliki pengaruh positif pada niat beli. Selain itu, sikap terhadap iklan terbukti memiliki efek mediasi secara parsial pada hubungan antara kredibitas endorser dengan niat beli.

Penelitian lainnya yang dilakukan oleh Ohanian (1990) mengamati kata sifat yang dapat menggambarkan kredibilitas endorser. Hasil penelitian menunjukkan bahwa kredibilitas endorser berhubungan erat dengan keahlian (expertise), kepercayaan (trustworthiness), dan daya tarik (attractiveness). Penelitian Yi (1990) mengamati pesan iklan yang dapat mempengaruhi efektivitas iklan pada sikap terhadap iklan dan merek hingga pada akhirnya secara tidak langsung mempengaruhi minat beli.

\section{Kerangka Pemikiran}

Berdasarkan penelitian Hemamalini dan Kurup (2014), penulis mencoba membangun model penelitian baru sesuai dengan gambar 2 . Variabel yang diambil berupa pesan iklan, keterlibatan iklan, dan minat beli. Variabel penggunaan selebritas dalam iklan dibagi menjadi dua variabel berbeda sesuai dengan penelitian Zafardan Rafique(2012) meliputi kredibilitas endorser dan kecocokan (atau kongruensi) endorser. Variabel daya tarik fisik ditampilkan secara terpisah dalam penelitian Zafar dan Rafique (2012). Akan tetapi, penulis mengikuti penelitian Aziz, et al (2013) untuk mengabungkan variabel daya tarik fisik menjadi salah satu dimensi untuk variabel kredibilitas endorser selain dimensi kepercayaan dan keahlian. Variabel lain yang ikut disertakan dalam penelitian ini adalah sikap terhadap iklan dan sikap terhadap merek yang mempengaruhi minat beli konsumen.

Sesuai dengan pertimbangan di atas, secara skematis, kerangka pemikiran atau model penelitian dapat terlihat dalam gambar 2 . 


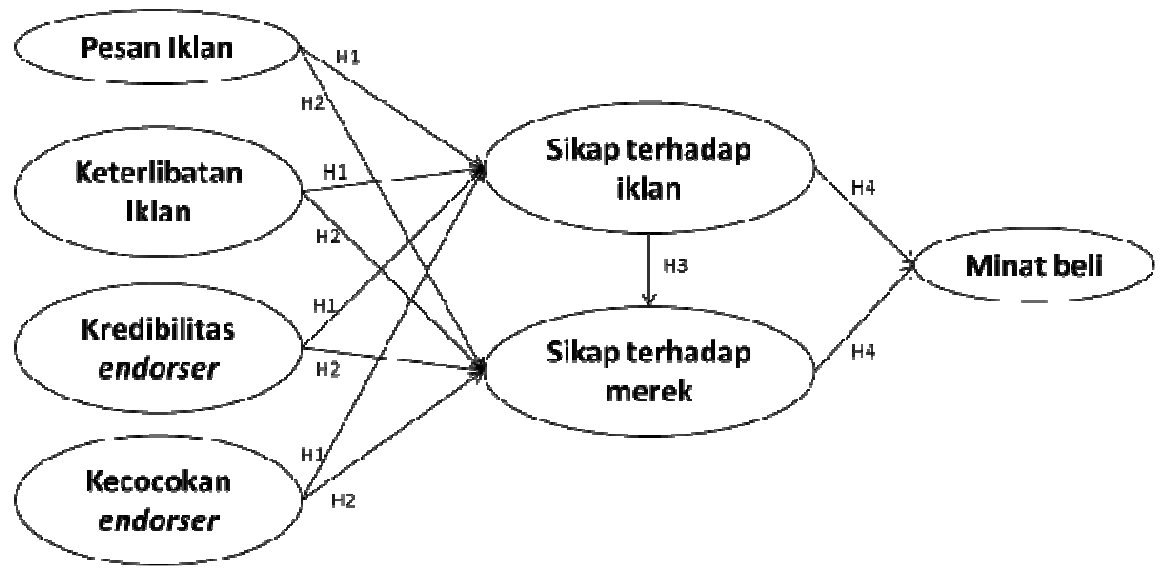

Sumber: Data primer.

Gambar 2. Kerangka pemikiran penelitian.

\section{Hipotesis Penelitian}

Sesuai dengan perumusan masalah yang dilakukan dalam bab pendahuluan, hipotesis untuk penelitian ini adalah sebagai berikut.

H1: Pesan iklan, keterlibatan iklan, kredibilitas endorser, dan kecocokan endorser berpengaruh positif pada sikap terhadap iklan Pharmaton ${ }^{\circledR}$ Formula.

H2: Pesan iklan, keterlibatan iklan, kredibilitas endorser, dan kecocokan endorser berpengaruh positif padasikap terhadap merek Pharmaton ${ }^{\circledR}$ Formula.

H3: Sikap terhadap iklan berpengaruh positif pada sikap terhadap merek Pharmaton ${ }^{\circledR}$ Formula.

H4: Sikap terhadap iklan dan sikap terhadap merek berpengaruh positif pada minat beli produk Pharmaton ${ }^{\circledR}$ Formula.

\section{METODE PENELITIAN}

\section{Subjek Penelitian}

Subjek penelitian adalah pekerja dengan rentang usia antara 23-45 tahun. Rentang usia pekerja antara 23-45 tahun dipilih karena konsumen yang berada dalam usia tersebut menjadi target pasar Pharmaton ${ }^{\circledR}$ Formula. Dengan pertimbangan kemudahan pengambilan sampel, teknik sampling yang digunakan adalah multistage random sampling. Pengacakan pertama dilakukan untuk menentukan salah satu dari lima wilayah di Jakarta yang akan dilakukan sampling. Setelah terpilih satu wilayah, dilakukan pengacakan kedua untuk menentukan mal yang akan dijadikan tempat melakukan sampling. Area mal dipilih sebagai tempat sampling karena relatif banyak pengunjung mal yang berusia antara 23 - 45 tahun. Selanjutnya, pengacakan ketiga adalah untuk menentukan hari dan waktu sampling agar setiap sampling dilakukan pada hari dan waktu yang berbeda.

\section{Objek Penelitian}

Produk yang menjadi objek dalam penelitian ini adalah Pharmaton ${ }^{\circledR}$ Formula, salah satu produk multivitamin mineral yang dipasarkan oleh PT Boehringer Ingelheim Indonesia. Pharmaton ${ }^{\circledR}$ Formula sudah tersedia lebih dari 50 tahun dan dipasarkan di lebih dari 80 negara di dunia. Sejumlah studi klinis menunjukkan bahwa penggunaan Pharmaton ${ }^{\circledR}$ Formula dapat membantu meningkatkan kapasitas fisik dan mental serta kualitas hidup konsumen. Selain kandungan multivitamin mineral lengkap, Pharmaton ${ }^{\circledR}$ Formula juga dilengkapi dengan ekstrak ginseng G115 terstandarisasi (kandungan senyawa aktif ginseng yang sama dalam setiap kapsul). Dengan bentuk berupa kapsul lunak dan penggunaan satu kapsul sekali sehari, Pharmaton ${ }^{\circledR}$ Formula juga menjadi salah satu pilihan produk multivitamin mineral untuk membantu menjaga stamina dan kesehatan.

\section{Variabel Penelitian}

Secara operasional, variabel perlu didefinisikan dengan tujuan untuk menjelaskan makna variabel penelitian. Variabel yang akan dianalisis dalam penelitian ini dikelompokkan menjadi :

1. Variabel bebas (independent variable) yaitu variabel yang diukur dan dipilih oleh peneliti untuk menentukan hubungannya dengan variabel lain yang akan diobservasi. Variabel bebas dalam penelitian ini adalah 
pesan iklan (M), kredibilitas endorser (CR), kecocokan endorser (C), dan keterlibatan iklan (I).

2. Variabel mediator dalam penelitian ini mencakup sikap terhadap iklan (AA) dan sikap terhadap merek (AB).

3. Variabel terikat (dependent variable) merupakan variabel yang dipengaruhi oleh variabel lain. Dalam penelitian ini, variabel terikat mencakup sikap terhadap iklan (AA), sikap terhadap merek (AB), dan minat beli (PI).

Skala yang digunakan untuk mengukur variabel kredibilitas endorser, sikap terhadap iklan, dan sikap terhadap merek mengikuti skala semantik diferensial. Dalam skala semantik diferensial, responden akan dihadapkan dengan pilihan di antara dua kata sifat berlawanan (seperti baik-buruk, suka-tidak suka, tinggi-rendah, dll) yang membentuk suatu continuum (Hair et al., 2003: 425). Skala diferensial yang dipilih memiliki alternatif jawaban antara 5 hingga 7 alternatif. Untuk penelitian ini, dipilih skala dengan 6 alternatif jawaban untuk menghindari respon yang bersifat netral.

Variabel pesan iklan, keterlibatan iklan, kecocokan endorser, dan minat beli akan diukur menggunakan skala Likert. Penggunaan skala Likert dilakukan dengan memberikan alternatif antara setuju dan tidak setuju dalam suatu rentang alternatif (Hair et al., 2003: 422). Sama halnya dengan pertimbangan sebelumnya, alternatif jawaban yang dipilih berjumlah enam dengan pilihan jawaban berikut:
a. Sangat setuju, diberikan skor 6
b. Setuju, diberikan skor 5 .
c. Cukup setuju, diberikan skor 4.
d. Agak tidak setuju, diberikan skor 3 .
e. Tidak setuju, diberikan skor 2 .
f. Sangat tidak setuju, diberikan skor 1 .

Variabel tersebut akan diukur dengan memperhatikan indikator yang diperoleh dari penelitian yang telah dilakukan sebelumnya. Variabel dan indikator yang akan digunakan dalam penelitian ini dapat dilihat dalam tabel 1 .

\section{Uji Instrumen Penelitian (Pre-Test)}

Dalam melakukan pengujian instrumen penelitian, perlu dilakukan pre-test kuesioner terhadap sekurang-kurangnya 30 responden.
Setelah itu, dilakukan uji validitas dan reliabilitas hasil pre-test. Uji reliabilitas dapat dilakukan dengan melihat nilai Cronbach's Alpha (CA), minimal 0,60. Untuk mengukur validitas variabel dengan skala interval, digunakan matriks korelasi Pearson dengan nilai yang direkomendasikan adalah minimal 0,03 untuk tingkat signifikansi 0,05 (Hair et al., 2003: 570).

\section{Structural Equation Modeling (SEM)}

Metode SEM digunakan dalam penelitian ini karena SEM lebih mampu menjelaskan hubungan antar variabel yang lebih kompleks serta mampu menguji rangkaian hubungan yang relatif rumit (Schumacker et al., 2010: 2). Dalam analisis dengan metode SEM, uji normalitas dan multikolinearitas merupakan asumsi klasik yang harus dipenuhi (Ghozali dan Fuad, 2005: 53). Uji normalitas dilakukan untuk memastikan apakah data membentuk distribusi normal atau tidak, dengan memperhatikan nilai skewness (di bawah dua), dan kurtosis (bernilai di bawah tujuh). Jika asumsi normalitas tidak terpenuhi dan penyimpangan normalitas tersebut besar, seluruh hasil uji statistik tidak valid. Perhitungan analisis SEM didasarkan pada asumsi bahwa data normal. Analisis multikolinearitas dilakukan untuk memastikan tidak adanya korelasi yang sempurna atau besar di antara variabel independen.

Analisis Faktor Konfirmatori (CFA) dilakukan untuk memberikan validasi model pengukuran dan mengamati hubungan antara indikator dengan variabel. Nilai loading factor yang dianjurkan adalah lebih besar dari 0,5 . Jumlah minimal indikator variabel laten yang fit adalah lebih besar atau sama dengan 3 (Jaccard and Wan, 1996: 72). Uji reliabilitas dilakukan terhadap setiap variabel laten dengan menggunakan informasi pada loading indikator dan error variance yang diperoleh dari standardized solutions dan nilai composite reliability yang baik adalah 0,6 (Ghozali dan Fuad, 2005: 40).

Rumus yang digunakan untuk menghitung reliabilitas adalah sebagai berikut:

$$
\rho-\left[\frac{(\Sigma \lambda)^{2}}{\left[(\Sigma \lambda)^{2}+\Sigma \theta\right]}\right]
$$

Dimana: $\boldsymbol{\rho}=$ composite reliability, $\boldsymbol{\lambda}=$ loading indikator, dan $\boldsymbol{\theta}=$ error variance indikator. 
Tabel 1: Definisi Operasional Variabel

\begin{tabular}{|c|c|c|c|}
\hline Variabel & Kode & Indikator & Sumber \\
\hline \multirow{4}{*}{$\begin{array}{l}\text { Pesan Iklan }(\mathbf{M}) \rightarrow \text { pesan } \\
\text { yang ditampilkan dalam iklan } \\
\text { (Buda dan Zhang, 2000) }\end{array}$} & M1 & Pesan penting ditampilkan di awal iklan tersebut & \multirow{4}{*}{$\begin{array}{l}\text { Hemamalini dan } \\
\text { Kurup (2014) }\end{array}$} \\
\hline & M2 & $\begin{array}{l}\text { Pesan iklan tersebut persuasif karena adanya } \\
\text { pengaruh endorser (pembawa pesan) }\end{array}$ & \\
\hline & M3 & $\begin{array}{l}\text { Iklan tersebut mempengaruhi niat beli karena pesan } \\
\text { iklan dapat dipercaya }\end{array}$ & \\
\hline & M4 & $\begin{array}{l}\text { Iklan tersebut mempengaruhi niat beli karena } \\
\text { menampilkan pesan positif }\end{array}$ & \\
\hline \multirow{14}{*}{$\begin{array}{l}\text { Kredibilitas Endorser } \\
(\mathbf{C R}) \rightarrow \text { istilah untuk } \\
\text { menyiratkan karakteristik } \\
\text { positif komunikator yang } \\
\text { mempengaruhi penerimaan } \\
\text { penerima pesan (Ohanian, } \\
\text { 1990) }\end{array}$} & CR1 & Menarik-Tidak Menarik & \multirow{14}{*}{ Ohanian (1990) } \\
\hline & CR2 & Berkelas-Tidak Berkelas & \\
\hline & CR3 & Tampan-Jelek & \\
\hline & CR4 & Elegan-Sederhana & \\
\hline & CR5 & Seksi-Tidak Seksi & \\
\hline & CR6 & Dapat diandalkan-Tidak dapat diandalkan & \\
\hline & CR7 & Jujur-Tidak jujur & \\
\hline & CR8 & Dapat dipercaya-Tidak dapat dipercaya & \\
\hline & CR9 & Tulus-Tidak tulus & \\
\hline & CR10 & Ahli-Tidak ahli & \\
\hline & CR11 & Berpengalaman-Tidak berpengalaman & \\
\hline & CR12 & Berpengetahuan-Tidak berpengetahuan & \\
\hline & CR13 & Berkualitas-Tidak berkualitas & \\
\hline & CR14 & Terampil-Tidak terampil & \\
\hline \multirow{5}{*}{$\begin{array}{l}\text { Kecocokan } \text { Endorser }(\mathbf{C}) \rightarrow \\
\text { kongruensi antara pembawa } \\
\text { pesan dengan produk atau } \\
\text { merek yang dibawakan } \\
\text { (Khatri, 2006) }\end{array}$} & $\mathrm{C} 1$ & Endorser termasuk orang yang terkenal & \multirow{5}{*}{$\begin{array}{l}\text { Zafar and Rafique } \\
\text { (2012) }\end{array}$} \\
\hline & $\mathrm{C} 2$ & $\begin{array}{l}\text { Citra endorser cocok dengan merek yang } \\
\text { diiklankan }\end{array}$ & \\
\hline & $\mathrm{C} 3$ & Merek yang diiklankan cocok dengan endorser & \\
\hline & $\mathrm{C} 4$ & $\begin{array}{l}\text { Endorser meyakinkan dalam membawakan merek } \\
\text { yang diiklankan }\end{array}$ & \\
\hline & $\mathrm{C} 5$ & $\begin{array}{l}\text { Endorser menggunakan produk yang diiklankan } \\
\text { dalam aktivitas sehari-hari }\end{array}$ & \\
\hline \multirow{4}{*}{$\begin{array}{l}\text { Keterlibatan Iklan (I) } \\
\rightarrow \text { isu spesifik tertentu } \\
\text { mengenai produk yang sedang } \\
\text { dipertimbangkan (Petty, } \\
\text { Cacciopo, and Schumann, } \\
\text { 1983) }\end{array}$} & I1 & $\begin{array}{l}\text { Iklan tersebut persuasif karena memberikan pesan } \\
\text { informatif mengenai produk }\end{array}$ & \multirow{4}{*}{$\begin{array}{l}\text { Hemamalini dan } \\
\text { Kurup (2014) }\end{array}$} \\
\hline & $\mathrm{I} 2$ & Iklan tersebut mendorong niat beli produk & \\
\hline & I3 & Iklan tersebut menampilkan artis sebagai endorser & \\
\hline & I4 & $\begin{array}{l}\text { Iklan tersebut mendorong niat beli karena pesan } \\
\text { iklan mudah dimengerti }\end{array}$ & \\
\hline \multirow{5}{*}{$\begin{array}{l}\text { Sikap Terhadap Iklan (AA) } \\
\rightarrow \text { perwakilan respon } \\
\text { konsumen yang } \\
\text { menyenangkan atau tidak } \\
\text { terhadap suatu iklan } \\
\text { (Solomon, 2009: } 287)\end{array}$} & AA1 & Baik-Buruk & \multirow{5}{*}{$\begin{array}{l}\text { Zafar and Rafique } \\
\text { (2012) }\end{array}$} \\
\hline & AA2 & Menarik-Tidak menarik & \\
\hline & AA3 & SukaTidak suka & \\
\hline & AA4 & Kreatif-Tidak kreatif & \\
\hline & AA5 & Informatif-Tidak informatif & \\
\hline \multirow{5}{*}{$\begin{array}{l}\text { Sikap Terhadap Merek (AB) } \\
\rightarrow \text { evaluasi menyeluruh } \\
\text { terhadap merek yang } \\
\text { dilakukan oleh konsumen } \\
\text { (Mehta, 1994) }\end{array}$} & $\mathrm{AB} 1$ & Baik-Buruk & \multirow{5}{*}{$\begin{array}{l}\text { Zafar and Rafique } \\
\text { (2012) }\end{array}$} \\
\hline & $\mathrm{AB} 2$ & Menyenangkan-Tidak menyenangkan & \\
\hline & AB3 & SukaTidak suka & \\
\hline & $\mathrm{AB} 4$ & Kualitas rendah-Kualitas tinggi & \\
\hline & AB5 & Memuaskan-Tidak memuaskan & \\
\hline \multirow{4}{*}{$\begin{array}{l}\text { Minat Beli (PI) } \\
\rightarrow \text { rencana kognitif atau } \\
\text { keinginan konsumen untuk } \\
\text { membeli suatu barang atau } \\
\text { merek tertentu (Solomon, } \\
\text { 2009: } 301 \text { ). }\end{array}$} & PI1 & Tertarik untuk mencoba produk tersebut & \multirow{4}{*}{ Yi (1990) } \\
\hline & PI2 & $\begin{array}{l}\text { Akan membeli produk tersebut jika terlihat dijual di } \\
\text { toko }\end{array}$ & \\
\hline & PI3 & $\begin{array}{l}\text { Akan aktif mencari produk tersebut di toko untuk } \\
\text { membelinya }\end{array}$ & \\
\hline & PI4 & Akan secara rutin membeli produk tersebut & \\
\hline
\end{tabular}

Kriteria Goodness of Fit digunakan sebagai pedoman untuk menguji apakah suatu model fit atau tidak. Tidak ada sebuah model fit yang memenuhi seluruh kriteria Goodness of Fit. Pemilihan kriteria yang harus memenuhi rentang harus mempertimbangkan tujuan dari pembentukan model. Semakin banyak kriteria yang terpenuhi menunjukkan bahwa model yang dibentuk didukung oleh data (Schumacker et al, 2010: 91).

Analisis struktural dilakukan dengan memperhatikan koefisien determinasi, koefi- 
sien regresi, dan nilai-t. Untuk melakukan pengujian terhadap hipotesis yang diajukan, perlu digunakan analisi regresi melalui uji t. Uji t dikenal dengan uji parsial, yaitu untuk menguji bagaimana pengaruh masing-masing variabel bebas terhadap variabel terikat.

\section{HASIL ANALISIS}

\section{Gambaran Umum Pharmaton ${ }^{\circledR}$ dan Oka Antara}

Pharmaton ${ }^{\circledR}$ adalah merek multivitamin dan suplemen mineral dalam portofolio Boehringer Ingelheim CHC dikembangkan untuk meningkatkan kapasitas fisik dan mental manusia. Pharmaton ${ }^{\circledR}$, produk untuk orang dewasa, berisi perpaduan unik dari vitamin, mineral dan elemen dan ekstrak ginseng $\mathrm{G} 115^{\circledR}$ terstandarisasi. Indikasi utama adalah untuk kelelahan, kelelahan, penurunan konsentrasi dan kewaspadaan mental. Beberapa studi klinis menunjukkan bahwa asupan rutin Pharmaton ${ }^{\circledR}$ berpengaruh positif pada kinerja mental dan fisik.

Nyoman Oka Wisnupada Antara atau yang lebih dikenal dengan nama Oka Antara (lahir di Jakarta, 8 Juli 1981) adalah seorang aktor Indonesia. Oka Antara mengawali kariernya di perfilman Indonesia pada tahun 2006 melalui film "Gue Kapok Jatuh Cinta". Oka semakin dikenal luas setelah bermain dalam film sukses "Ayat-Ayat Cinta" arahan Hanung Bramantyo. Oka sempat bermain dalam film drama "Hari Untuk Amanda" di mana ia mendapat beberapa nominasi dan sebuah penghargaan untuk perannya. Pada tahun 2012, Oka Antara dipilih oleh duet sutradara Timo Tjahjanto dan Kimo Stamboel, the Mo Brothers, sebagai peran utama dalam film bergenre psycological thriller yang diberi judul "Killers". Dalam film yang juga di produseri oleh Gareth Evans ini, Oka beradu akting dengan aktor jepang Kazuki Kitamura. Oka Antara juga bermain dalam sekuel film action sukses "The Raid" yang diberi judul "Berandal".

\section{Analisis Hasil Uji Instrumen Penelitian (Pre- Test)}

Uji reliabilitas penelitian ini dilakukan dengan mengamati nilai Cronbach's Alpha (CA). Pengujian ini dilakukan melalui pengolahan data menggunakan SPSS versi 22. Hasil uji reabilitas dapat dilihat dalam tabel 2 .

Tabel 2: NilaiCronbach's Alpha (CA) Instrumen Penelitian

\begin{tabular}{|c|c|c|c|}
\hline Variabel & Kode & $\begin{array}{c}\text { CA if item } \\
\text { deleted }\end{array}$ & $\mathbf{C A}$ \\
\hline \multirow{4}{*}{$\begin{array}{l}\text { Pesan Iklan } \\
\text { (M) }\end{array}$} & M1 & 0.702 & \multirow{4}{*}{$\begin{array}{l}0.746 \\
(\mathrm{~N}=4)\end{array}$} \\
\hline & M2 & 0.610 & \\
\hline & M3 & 0.683 & \\
\hline & M4 & 0.742 & \\
\hline \multirow{14}{*}{$\begin{array}{l}\text { Kredibilitas } \\
\text { Endorser } \\
\text { (CR) }\end{array}$} & CR1 & 0.940 & \multirow{14}{*}{$\begin{array}{c}0.941 \\
(\mathrm{~N}=14)\end{array}$} \\
\hline & CR2 & 0.937 & \\
\hline & CR3 & 0.941 & \\
\hline & CR4 & 0.941 & \\
\hline & CR5 & 0.937 & \\
\hline & CR6 & 0.938 & \\
\hline & CR7 & 0.935 & \\
\hline & CR8 & 0.935 & \\
\hline & CR9 & 0.935 & \\
\hline & CR10 & 0.936 & \\
\hline & CR11 & 0.936 & \\
\hline & CR12 & 0.936 & \\
\hline & CR13 & 0.936 & \\
\hline & CR14 & 0.934 & \\
\hline \multirow{5}{*}{$\begin{array}{l}\text { Kecocokan } \\
\text { Endorser (C) }\end{array}$} & $\mathrm{C} 1$ & 0.884 & \multirow{5}{*}{$\begin{array}{l}0.893 \\
(\mathrm{~N}=5)\end{array}$} \\
\hline & $\mathrm{C} 2$ & 0.859 & \\
\hline & C3 & 0.848 & \\
\hline & $\mathrm{C} 4$ & 0.877 & \\
\hline & C5 & 0.882 & \\
\hline \multirow{4}{*}{$\begin{array}{l}\text { Keterlibatan } \\
\text { Iklan (I) }\end{array}$} & I1 & 0.715 & \multirow{4}{*}{$\begin{array}{l}0.817 \\
(\mathrm{~N}=4)\end{array}$} \\
\hline & I2 & 0.696 & \\
\hline & I3 & 0.815 & \\
\hline & I4 & 0.738 & \\
\hline \multirow{5}{*}{$\begin{array}{l}\text { Sikap } \\
\text { Terhadap } \\
\text { Iklan (AA) }\end{array}$} & AA1 & 0.922 & \multirow{5}{*}{$\begin{array}{l}0.937 \\
(\mathrm{~N}=5)\end{array}$} \\
\hline & AA2 & 0.925 & \\
\hline & AA3 & 0.907 & \\
\hline & AA4 & 0.929 & \\
\hline & AA5 & 0.925 & \\
\hline \multirow{5}{*}{$\begin{array}{l}\text { Sikap } \\
\text { Terhadap } \\
\text { Merek (AB) }\end{array}$} & AB1 & 0.924 & \multirow{5}{*}{$\begin{array}{l}0.934 \\
(\mathrm{~N}=5)\end{array}$} \\
\hline & $\mathrm{AB} 2$ & 0.908 & \\
\hline & AB3 & 0.912 & \\
\hline & AB4 & 0.927 & \\
\hline & AB5 & 0.925 & \\
\hline \multirow{4}{*}{$\begin{array}{l}\text { Minat Beli } \\
\text { (PI) }\end{array}$} & PI1 & 0.958 & \multirow{4}{*}{$\begin{array}{l}0.958 \\
(\mathrm{~N}=4)\end{array}$} \\
\hline & PI2 & 0.932 & \\
\hline & PI3 & 0.942 & \\
\hline & PI4 & 0.933 & \\
\hline
\end{tabular}

Sumber: Data primer.

Berdasarkan tabel 2, nilai CA instrumen penelitian ini berada dalam rentang 0,746 (M) hingga 0,958 (PI)sehingga memenuhi syarat reliabilitas dan dapat digunakan sebagai instrumen penelitian. 
Tabel 3: Nilai Korelasi Pearson (KP) Instrumen Penelitian

\begin{tabular}{|c|c|c|c|c|c|}
\hline Variabel & Kode & $\mathbf{K P}$ & Variabel & Kode & $\mathbf{K P}$ \\
\hline \multirow{4}{*}{$\begin{array}{l}\text { Pesan Iklan } \\
\text { (M) }\end{array}$} & M1 & $0.736^{* * *}$ & \multirow{5}{*}{$\begin{array}{l}\text { Kecocokan } \\
\text { Endorser } \\
\text { (C) }\end{array}$} & $\mathrm{C} 1$ & $0.796^{\text {**a }}$ \\
\hline & M2 & $0.835^{* *}$ & & $\mathrm{C} 2$ & $0.870^{\text {**k }}$ \\
\hline & M3 & $0.753^{* * *}$ & & C3 & $0.902^{* *}$ \\
\hline & M4 & $0.687^{* *}$ & & $\mathrm{C} 4$ & $0.813^{* * k}$ \\
\hline \multirow{14}{*}{$\begin{array}{l}\text { Kredibilitas } \\
\text { Endorser } \\
\text { (CR) }\end{array}$} & CR1 & $0.662^{* * *}$ & & C5 & 0.812 \\
\hline & CR2 & $0.743^{* * *}$ & \multirow{5}{*}{$\begin{array}{l}\text { Sikap } \\
\text { Terhadap } \\
\text { Iklan (AA) }\end{array}$} & AA1 & $0.894^{* * *}$ \\
\hline & CR3 & $0.606^{* *}$ & & AA2 & $0.890^{* \cdots *}$ \\
\hline & CR4 & $0.616^{* * *}$ & & AA3 & $0.945^{* * *}$ \\
\hline & CR5 & $0.767^{* *}$ & & AA4 & $0.869^{* \cdots *}$ \\
\hline & CR6 & $0.723^{* *}$ & & AA5 & $0.879^{\text {*** }}$ \\
\hline & CR7 & $0.808^{* *}$ & \multirow{5}{*}{$\begin{array}{l}\text { Sikap } \\
\text { Terhadap } \\
\text { Merek (AB) }\end{array}$} & $\mathrm{AB} 1$ & $0.869^{* \cdots *}$ \\
\hline & CR8 & $0.825^{* * *}$ & & $\mathrm{AB} 2$ & $0.932^{\text {*** }}$ \\
\hline & CR9 & $0.812^{* *}$ & & AB3 & $0.922^{* * * k}$ \\
\hline & CR10 & $0.801^{* *}$ & & $\mathrm{AB} 4$ & $0.865^{* * k}$ \\
\hline & CR11 & 0.776 * & & AB5 & $0.870^{* * *}$ \\
\hline & CR12 & $0.779^{* * *}$ & \multirow{4}{*}{$\begin{array}{l}\text { Minat Beli } \\
(\mathrm{PI})\end{array}$} & PI1 & $0.888^{* k}$ \\
\hline & CR13 & $0.800 *$ & & PI2 & $0.965^{* * 2}$ \\
\hline & CR14 & $0.855^{* * *}$ & & PI3 & $0.950^{* 3 * 2}$ \\
\hline \multirow{4}{*}{$\begin{array}{l}\text { Keterlibatan } \\
\text { Iklan (I) }\end{array}$} & I1 & $0.877^{* * 2}$ & & PI4 & $0.964^{* * *}$ \\
\hline & $\mathrm{I} 2$ & $0.892^{* * *}$ & \multirow{3}{*}{\multicolumn{3}{|c|}{$\begin{array}{l}\text { **. Correlation is significant at the } \\
0.01 \text { level (2-tailed). }\end{array}$}} \\
\hline & I3 & $0.578^{* *}$ & & & \\
\hline & I4 & $0.843^{* * *}$ & & & \\
\hline
\end{tabular}

Sumber: Data primer.

Berdasarkan tabel 3, seluruh indikator memiliki nilai KP yang lebih besar dari 0,03 dengan tingkat signifikansi 0,01 sehingga memenuhi syarat validitas (Hair et al., 2003:
570) dan dapat digunakan sebagai instrumen penelitian. Dengan demikian, seluruh indikator dapat digunakan sebagai instrumen penelitian dalam uji selanjutnya.

\section{Profil Responden}

Tabel 4

\begin{tabular}{|c|c|c|c|}
\hline Karakteristik & Jumlah & Per: & $(\%)$ \\
\hline Jenis Kelamin & 410 & 100 & \\
\hline Laki-laki & 239 & & 58,3 \\
\hline Perempuan & 171 & & 41,7 \\
\hline Usia & 410 & 100 & \\
\hline 23-32 tahun & 340 & & 82,9 \\
\hline 33-42 tahun & 57 & & 13,9 \\
\hline$>43$ tahun & 13 & & 3,2 \\
\hline Pendidikan terakhir & 410 & 100 & \\
\hline SMA & 47 & & 11,5 \\
\hline D3 & 23 & & 5,6 \\
\hline S1 & 263 & & 64,1 \\
\hline S2 & 42 & & 10,2 \\
\hline Lainnya & 35 & & 8,5 \\
\hline Durasi bekerja dalam sehari & 410 & 100 & \\
\hline$<6 \mathrm{jam}$ & 42 & & 10,2 \\
\hline 6-8 jam & 161 & & 39,3 \\
\hline 8-10 jam & 165 & & 40,3 \\
\hline$>10 \mathrm{jam}$ & 42 & & 10,2 \\
\hline Pengeluaran bulanan & 410 & 100 & \\
\hline <Rp. 1.000 .000 & 32 & & 7,8 \\
\hline Rp. $1.000 .001-2.500 .000$ & 130 & & 31,7 \\
\hline Rp. 2.500.001-5.000.000 & 150 & & 36,6 \\
\hline Rp. 5.000.001-10.000.000 & 67 & & 16,3 \\
\hline$>$ Rp. 10.000 .000 & 31 & & 7,6 \\
\hline
\end{tabular}

Karakteristik umum responden $(\mathrm{n}=410)$

Sumber: Data primer. 
Karakteristik umum ini sesuai dengan target utama konsumen Pharmaton ${ }^{\circledR}$ Formula yaitu laki-laki dengan usia pekerja (23-45 tahun) dan memiliki aktivitas harian yang tinggi (dari sisi durasi bekerja dalam sehari) serta tergolong dalam kelas ekonomi menengah ke atas (dilihat dari pengeluaran bulanan). Sebagian besar responden sudah mengetahui produk Pharmaton ${ }^{\circledR}$ Formula $(86,1 \%)$. Selain itu, tabel tersebut juga memperlihatkan bahwa mayoritas responden penelitian $(82,4 \%)$ juga sudah pernah melihat iklan Pharmaton ${ }^{\circledR}$ Formula. Dengan demikian, sebagian besar responden diharapkan tidak kesulitan dalam menjawab pertanyaan berikutnya terkait dengan produk dan iklan Pharmaton ${ }^{\circledR}$ Formula.

\section{Uji SEM}

Tabel 5: Tabel Uji Normalitas

\begin{tabular}{|c|c|c|c|}
\hline Variabel & Kode & Skewness & Kurtosis \\
\hline \multirow{4}{*}{ Pesan Iklan (M) } & M1 & -0.726 & -0.813 \\
\hline & M2 & -0.323 & -0.703 \\
\hline & M3 & -0.229 & -0.660 \\
\hline & M4 & -0.566 & -1.376 \\
\hline \multirow{14}{*}{ Kredibilitas Endorser (CR) } & CR1 & -0.407 & 0.918 \\
\hline & CR2 & -0.340 & 0.970 \\
\hline & CR3 & -0.552 & -1.065 \\
\hline & CR4 & -0.099 & -0.714 \\
\hline & CR5 & -0.028 & -0.658 \\
\hline & CR6 & -0.399 & -0.423 \\
\hline & CR7 & -0.318 & -0.233 \\
\hline & CR8 & -0.379 & -0.479 \\
\hline & CR9 & -0.368 & -0.457 \\
\hline & CR10 & -0.172 & -1.101 \\
\hline & CR11 & -0.496 & -1.032 \\
\hline & CR12 & -0.413 & -0.407 \\
\hline & CR13 & -0.587 & -0.984 \\
\hline & CR14 & -0.488 & -0.979 \\
\hline \multirow{5}{*}{ Kecocokan Endorser ( $\mathbb{C}$} & $\mathrm{C} 1$ & -0.593 & -1.195 \\
\hline & $\mathrm{C} 2$ & -0.440 & -0.938 \\
\hline & $\mathrm{C} 3$ & -0.351 & -0.704 \\
\hline & $\mathrm{C} 4$ & -0.403 & -0.607 \\
\hline & $\mathrm{C} 5$ & -0.060 & -0.955 \\
\hline \multirow{4}{*}{ Keterlibatan Iklan (I) } & $\mathrm{I} 1$ & -0.726 & -0.866 \\
\hline & $\mathrm{I} 2$ & -0.274 & -0.910 \\
\hline & $\mathrm{I} 3$ & -0.833 & -1.494 \\
\hline & $\mathrm{I} 4$ & -0.704 & -1.145 \\
\hline \multirow{5}{*}{ Sikap Terhadap Iklan (AA) } & AA1 & -0.540 & -0.622 \\
\hline & AA2 & -0.427 & -0.974 \\
\hline & AA3 & -0.380 & -0.816 \\
\hline & AA4 & -0.324 & -1.165 \\
\hline & AA5 & -0.809 & -1.138 \\
\hline \multirow{5}{*}{ Sikap Terhadap Merek (AB) } & $\mathrm{AB} 1$ & -0.527 & -0.180 \\
\hline & AB2 & -0.384 & -0.109 \\
\hline & AB3 & -0.423 & -0.007 \\
\hline & $\mathrm{AB} 4$ & -0.335 & -0.259 \\
\hline & AB5 & -0.311 & -0.277 \\
\hline \multirow{4}{*}{ Minat Beli (PI) } & PI1 & 0.082 & -1.609 \\
\hline & $\mathrm{PI} 2$ & 0.585 & -1.629 \\
\hline & $\mathrm{PI} 3$ & 1.241 & -2.225 \\
\hline & PI4 & 1.739 & -3.085 \\
\hline
\end{tabular}

Sumber: Data primer. 
Tabel 5 memperlihatkan bahwa seluruh nilai skewness indikator berada di bawah nilai dua dan seluruh nilai kurtosis indikator berada di bawah nilai tujuh sehingga dapat disimpulkan bahwa data yang diperoleh dari penelitian memiliki distribusi yang normal dan dapat digunakan untuk tahap analisis selanjutnya.

Dari tabel 6 dapat disimpulkan bahwa variabel yang didapatkan dari penelitian tidak memiliki korelasi yang sempurna. Dengan demikian, data penelitian memenuhi asumsi multikolinearitas dan dapat digunakan untuk tahap analisis berikutnya pada SEM.

Tabel 7 merupakan rangkuman dari uji relibilitas gabungan. Berdasarkan uji tersebut, ditemukan bahwa seluruh variabel memiliki reliabilitas yang baik dengan nilai di atas 0,6. Nilai reliabilitas terendah terdapat pada variabel $\mathrm{M}$ (pesan iklan) dengan nilai 0,820 dan nilai tertinggi pada variabel CR (kredibilitas endorser) dengan skor 0,961 .

Tabel 6: Matriks Korelasi Antar Variabel

\begin{tabular}{cccccccc}
\hline Variabel & AA & AB & PI & M & I & C & CR \\
\hline AA & 0.99 & - & - & - & - & - & - \\
\hline AB & 0.79 & 0.99 & - & - & - & - & - \\
\hline PI & 0.53 & 0.59 & 1.01 & - & - & - & - \\
\hline M & 0.72 & 0.65 & 0.42 & 1.00 & - & - & - \\
\hline I & 0.84 & 0.74 & 0.48 & 0.75 & 1.00 & - & - \\
\hline C & 0.72 & 0.64 & 0.42 & 0.73 & 0.83 & 1.00 & - \\
\hline CR & 0.74 & 0.66 & 0.43 & 0.70 & 0.70 & 0.79 & 1.00 \\
\hline
\end{tabular}

Sumber: Data primer.

Tabel 7.

\begin{tabular}{|c|c|c|c|}
\hline Variabel & Kode & $\lambda$ & $\rho$ \\
\hline \multirow{4}{*}{$\begin{array}{l}\text { Pesan Iklan } \\
\text { (M) }\end{array}$} & M1 & 0.56 & \multirow{4}{*}{0.820} \\
\hline & M2 & 0.69 & \\
\hline & M3 & 0.82 & \\
\hline & M4 & 0.83 & \\
\hline \multirow{14}{*}{$\begin{array}{l}\text { Kredibilitas } \\
\text { Endorser } \\
\text { (CR) }\end{array}$} & CR1 & 0.79 & \multirow{14}{*}{0.961} \\
\hline & CR2 & 0.82 & \\
\hline & CR3 & 0.78 & \\
\hline & CR4 & 0.55 & \\
\hline & CR5 & 0.58 & \\
\hline & CR6 & 0.82 & \\
\hline & CR7 & 0.83 & \\
\hline & CR8 & 0.83 & \\
\hline & CR9 & 0.79 & \\
\hline & CR10 & 0.83 & \\
\hline & CR11 & 0.86 & \\
\hline & CR12 & 0.86 & \\
\hline & CR13 & 0.89 & \\
\hline & CR14 & 0.87 & \\
\hline \multirow{5}{*}{$\begin{array}{l}\text { Kecocokan } \\
\text { Endorser }(\mathrm{C})\end{array}$} & $\mathrm{C} 1$ & 0.82 & \multirow{5}{*}{0.914} \\
\hline & $\mathrm{C} 2$ & 0.90 & \\
\hline & $\mathrm{C} 3$ & 0.89 & \\
\hline & $\mathrm{C} 4$ & 0.82 & \\
\hline & $\mathrm{C} 5$ & 0.68 & \\
\hline
\end{tabular}

\begin{tabular}{|c|c|c|c|}
\hline Variabel & Kode & $\lambda$ & $\rho$ \\
\hline \multirow{4}{*}{$\begin{array}{l}\text { Keterlibatan } \\
\text { Iklan (I) }\end{array}$} & I1 & 0.87 & \multirow{4}{*}{0.886} \\
\hline & $\mathrm{I} 2$ & 0.83 & \\
\hline & I3 & 0.69 & \\
\hline & I4 & 0.85 & \\
\hline \multirow{5}{*}{$\begin{array}{l}\text { Sikap Terhadap } \\
\text { Iklan (AA) }\end{array}$} & AA1 & 0.83 & \multirow{5}{*}{0.913} \\
\hline & AA2 & 0.90 & \\
\hline & AA3 & 0.88 & \\
\hline & AA4 & 0.74 & \\
\hline & AA5 & 0.76 & \\
\hline \multirow{5}{*}{$\begin{array}{l}\text { Sikap Terhadap } \\
\text { Merek (AB) }\end{array}$} & $\mathrm{AB} 1$ & 0.87 & \multirow{5}{*}{0.946} \\
\hline & $\mathrm{AB} 2$ & 0.89 & \\
\hline & AB3 & 0.89 & \\
\hline & $\mathrm{AB} 4$ & 0.87 & \\
\hline & AB5 & 0.89 & \\
\hline \multirow{4}{*}{ Minat Beli (PI) } & PI1 & 0.85 & \multirow{4}{*}{0.943} \\
\hline & $\mathrm{PI} 2$ & 0.92 & \\
\hline & PI3 & 0.93 & \\
\hline & PI4 & 0.89 & \\
\hline
\end{tabular}

Reliabilitas gabungan data empiris

Sumber: Data primer. 
Tabel 8: Pengukuran Goodness Of Fit

\begin{tabular}{|c|c|c|c|c|}
\hline $\begin{array}{l}\text { Pengukuran } \\
\text { Fit }\end{array}$ & Good Fit & Acceptable Fit & $\begin{array}{c}\text { Model } \\
\text { Penelitian }\end{array}$ & Kesimpulan \\
\hline RMSEA & $0 \leq$ RMSEA $\leq .05$ & $.05<\mathrm{RMSEA} \leq .08$ & 0.038 & Good Fit \\
\hline SRMR & $0 \leq \mathrm{SRMR} \leq .05$ & $.05<$ SRMR $\leq .10$ & 0.056 & Good Fit \\
\hline NFI & $.95 \leq \mathrm{NFI} \leq 1.00$ & $.90 \leq \mathrm{NFI}<.95$ & 0.97 & Good Fit \\
\hline NNFI & $.97 \leq \mathrm{NNFI} \leq 1.00$ & $.95 \leq \mathrm{NNFI}<.97$ & 0.98 & Good Fit \\
\hline CFI & $.97 \leq \mathrm{CFI} \leq 1.00$ & $.95 \leq \mathrm{CFI}<.97$ & 0.98 & Good Fit \\
\hline AIC & \multicolumn{2}{|c|}{$\begin{array}{c}\text { Smaller than AIC for comparison } \\
\text { model }\end{array}$} & $\begin{array}{c}1722.00< \\
3101.41\end{array}$ & Good Fit \\
\hline CAIC & \multicolumn{2}{|c|}{$\begin{array}{c}\text { Smaller than CAIC for comparison } \\
\text { model }\end{array}$} & $\begin{array}{c}3593.47< \\
6045.10 \\
\end{array}$ & Good Fit \\
\hline ECVI & \multicolumn{2}{|c|}{$\begin{array}{c}\text { Smaller than ECVI for comparison } \\
\text { model }\end{array}$} & $4.19<7.55$ & Good Fit \\
\hline
\end{tabular}

Sumber: Data primer.

Berdasarkan ringkasan pengukuran goodness of fit model penelitian dapat dikategorian sebagai model yang fit karena telah memenuhi minimal tiga atau empat kriteria goodness of fit. Nilai RMSEA model penelitian adalah 0,038 dan berada dalam rentang RMSEA 0 hingga 0,05 sehingga memenuhi persyaratan fit. Begitu pula dengan nilai SRMR $(0,056)$, NFI $(0,97)$, NNFI $(0,98)$, CFI $(0,98)$ yang berada dalam rentang kriteria good fit. AIC model $(1722,00)$ lebih kecil daripada comparison model $(3101,41)$ sehingga dapat dikategorikan sebagai good fit. Skor CAIC model $(3593,47)$ lebih kecil daripada skor comparison model $(6045,10)$ sehingga memenuhi kriteria good fit. Nilai ECVI $(4,19)$ lebih kecil daripada nilai comparison model $(7,55)$ sehingga mendukung model yang fit.

Pengujian hipotesis dilakukan dengan memperhatikan nilai t pada signifikansi 0,05 . Nilai $\mathrm{t}$ yang harus dipenuhi adalah 1,96 (dengan $\mathrm{n}=410$ ). Jika nilai $\mathrm{t}$ hitung lebih kecil daripada $\mathrm{t}$ tabel, maka hipotesa alternatif ditolak dan hipotesa nol diterima. Tabel 9 menjelaskan mengenai uji hipotesis pada model penelitian.

Tabel 9: Rangkuman Uji Hipotesis Model Penelitian

\begin{tabular}{cccccc}
\hline Hipotesis & $\begin{array}{c}\text { Variabel } \\
\text { Bebas }\end{array}$ & $\begin{array}{c}\text { Variabel } \\
\text { Terikat }\end{array}$ & Estimates & $\begin{array}{c}\text { Nilai t } \\
\text { hitung }\end{array}$ & Kesimpulan \\
\hline H1 & M & AA & 1.52 & 3.62 & Diterima* \\
\hline H1 & I & AA & 2.34 & 4.77 & Diterima* \\
\hline H1 & C & AA & 0.65 & 3.04 & Diterima* \\
\hline H1 & CR & AA & 0.69 & 4.79 & Diterima* \\
\hline H2 & M & AB & 1.17 & 4.12 & Diterima* \\
\hline H2 & I & AB & 1.87 & 5.72 & Diterima* \\
\hline H2 & C & AB & 0.52 & 3.20 & Diterima* \\
\hline H2 & CR & AB & 0.58 & 5.01 & Diterima* \\
\hline H3 & AA & AB & 1.65 & 7.96 & Diterima* \\
\hline H4 & AA & PI & 0.18 & 2.25 & Diterima* \\
\hline H4 & AB & PI & 0.45 & 5.58 & Diterima* \\
\hline
\end{tabular}

Sumber: Data primer.

Keterangan: $*=$ signifikan pada $\mathrm{p}=0.05$.

Seperti yang diperlihatkan pada tabel 9 , untuk terdapat pengaruh positif yang signifikan antara pesan iklan (M), keterlibatan iklan (I), 
kredibilitas endorser (C), dan kecocokan endorser (CR) pada sikap terhadap iklan (AA) Pharmaton ${ }^{\circledR}$ Formula. Hasil ini sesuai dengan penelitian yang dilakukan sebelumnya oleh Zafar and Rafique (2012); Aziz, Ghani, and Niazi (2013); dan Hemamalini and Kurup (2014). Kredibilitas dan kecocokan/ kongruensi endorser mempengaruhi sikap terhadap iklan sesuai dengan hasil penelitian Zafardan Rafique (2012). Pesan iklan mempengaruhi dua konteks iklan yaitu konteks kognitif dan konteks afektif. Konteks kognitif mempengaruhi atribut produk, sedangkan konteks afektif mempengaruhi perasaan (Yi, 1990). Buda dan Zhang (2000) menjelaskan bahwa pesan positif yang ditampilkan di awal iklan oleh sumber yang tidak "ahli" memberikan pengaruh yang besar, sama halnya dengan pesan positif yang ditayangkan di akhir iklan oleh sumber yang "ahli". Untuk iklan dengan keterlibatan yang rendah seperti tentang kesehatan, pesan dengan konteks positif akan lebih mempengaruhi konsumen dibandingkan pesan negatif, dan sebaliknya (Maheswarandan Meyers-Levy, 1990). Dalam penelitian ini, pengaruh pesan iklan, keterlibatan iklan, kredibilitas endorser, dan kecocokan endorser pada sikap terhadap iklan cukup besar (73\%). Hal ini menunjukkan bahwa konsumen dipengaruhi oleh pesan yang disampaikan dalam iklan, keterlibatan (tingkat kepentingan) iklan, kredibilitas bintang iklan, serta kecocokan antara bintang iklan dengan produk yang diiklankan.

Selanjutnya, untuk pengujian hipotesis kedua, dapat teramati juga bahwa terdapat pengaruh positif yang signifikan antara pesan iklan, keterlibatan iklan, kredibilitas endorser, dan kecocokan endorser pada sikap terhadap merek (AB) Pharmaton $^{\circledR}$ Formula. Hasil penelitian ini sejalan dengan pengamatan Zafardan Rafique (2012) yang menunjukkan bahwa daya tarik fisik, kredibilitas, dan kongruensi atau kecocokan selebritas dalam iklan memberikan dampak terhadap persepsi konsumen mengenai produk yang disampaikan dalam iklan. Daya tarik fisik endorser akan meningkatkan evaluasi terhadap karakteristik produk hanya jika karakteristik produk "cocok" dengan karakter/ kesan yang ditampilkan endorser selebritas. Seperti yang telah dijelaskan sebelumnya, pesan iklan juga mempengaruhi sikap terhadap merek/ produk melalui konteks kognitif yang ditampilkan karena konteks kognitif akan mempengaruhi atribut suatu produk (Yi, 1990).

Pengujian hipotesis ketiga juga memperlihatkan pengaruh positif sikap terhadap iklan pada sikap terhadap merek Pharmaton ${ }^{\circledR}$ Formula. Penelitian ini memberikan hasil bahwa pengaruh pesan iklan, keterlibatan iklan, kredibilitas endorser, kecocokan endorser, dan sikap terhadap iklan pada sikap terhadap merek masih tergolong cukup besar (67\%). Hal ini menunjukkan bahwa sikap konsumen terhadap suatu merek atau produk dipengaruhi oleh pesan yang ditampilkan dalam iklan, keterlibatan (tingkat kepentingan) iklan, kredibilitas bintang iklan atau selebritas, kecocokan "gambar" antara bintang iklan dengan produk yang diiklankan, serta sikap konsumen terhadap iklan produk tersebut.

Sesuai dengan tabel 9, untuk pengujian hipotesis keempat, terlihat bahwa terdapat pengaruh yang signifikan antara sikap terhadap iklan dan sikap terhadap merek dengan minat beli (PI) produk Pharmaton ${ }^{\circledR}$ Formula. Sikap terhadap iklan dan sikap terhadap merek memiliki hubungan positif dengan minat beli. Walaupun demikian, sikap terhadap iklan dan sikap terhadap merek hanya memberikan pengaruh sebesar $36 \%$ pada minat beli produk. Hal ini menunjukkan terdapat hal atau faktor lain yang mempengaruhi minat beli suatu produk multivitamin seperti Pharmaton $^{\circledR}$ Formula.

\section{PEMBAHASAN}

\section{Implikasi Manajerial}

Dalam strategi promosi, iklan menjadi salah satu pilihan untuk menampilkan keunggulan suatu produk dengan cara yang khusus. Suatu iklan dengan pesan tertentu dan cara serta kemasan yang menarik dan unik akan lebih mudah menarik konsumen dalam membeli produk yang diiklankan tersebut. Dalam kasus ini, Pharmaton ${ }^{\circledR}$ Formula merupakan produk multivitamin mineral yang diiklankan dan Oka Antara menjadi endorser untuk iklan Pharmaton $^{\circledR}$ Formula. Beberapa faktor yang diperhatikan dalam penelitian ini adalah faktor pesan, kecocokan endorser dengan produk, kredibilitas endorser, serta keterlibatan iklan.

Pesan yang ditampilkan dalam iklan menjadi hal yang sangat penting. Dalam penelitian ini, pesan memiliki hubungan yang 
positif terhadap sikap terhadap iklan dan merek. Dengan pesan yang sesuai, konsumen akan memiliki sikap terhadap iklan dan merek yang diharapkan. Iklan Pharmaton ${ }^{\circledR}$ Formula memiliki pesan yang berdampak positif terhadap sikap konsumen sehingga pesan iklan perlu dirancang dengan baik agar terwujud sikap konsumen yang positif dan mendukung terhadap merek.

Kecocokan endorser dengan produk juga memiliki hubungan positif terhadap sikap terhadap iklan dan merek. Pemilihan suatu endorser baik selebritas maupun non selebritas menjadi hal yang tidak kalah penting. Endorser yang dianggap cocok dengan suatu produk akan lebih mendorong sikap positif konsumen terhadap iklan dan merek produk yang diiklankan. Sejalan dengan kecocokan endorser tersebut, kredibilitas endorser juga perlu dipertimbangkan dengan matang karena endorser akan menjadi ambassador dari merek dan produk yang diiklankan. Kredibilitas endorser terbagi atas tiga faktor utama, yaitu faktor kepercayaan, faktor keahlian, dan faktor daya tarik (Ohanian, 1990). Dalam pemilihan endorser, faktor tersebut sebaiknya dijadikan pedoman agar endorser yang terpilih dapat mendukung sikap terhadap iklan dan merek produk yang diiklankan.

Sesuai dengan hasil penelitian, keterlibatan iklan memberikan dampak positif terhadap sikap konsumen terhadap iklan dan merek Pharmaton ${ }^{\circledR}$ Formula. Produk multivitamin mineral memiliki keterlibatan iklan yang rendah sehingga pesan positif perlu dirancang agar terwujud sikap positif konsumen terhadap iklan dan merek produk yang diiklankan.

Menurut hasil penelitian, sikap terhadap iklan memberikan pengaruh positif terhadap sikap terhadap merek. Pembentukan sikap konsumen yang positif terhadap iklan yang ditampilkan akan memberikan sikap positif pula terhadap merek produk yang diiklankan sehingga pemilihan endorser dan pesan iklan perlu dipertimbangkan secara baik agar respon dari konsumen dapat diperoleh sesuai dengan respon yang diharapkan.

Sikap terhadap iklan dan merek memiliki dampak positif terhadap minat beli konsumen. Oleh karena itu, iklan yang dibentuk perlu mempertimbangkan faktor yang sebelumnya telah dibahas, yaitu pesan iklan, kecocokan endorser, kredibilitas endorser, dan keterlibatan iklan. Dengan demikian, secara tidak langsung keempat faktor tersebut mempengaruhi minat beli konsumen terhadap produk yang diiklankan.

Namun demikian, hasil dari studi pendahuluan yang telah dilakukan sebelumnya menunjukkan bahwa hanya sekitar 30\% responden yang berpendapat bahwa iklan mempengaruhi minat beli terhadap produk multivitamin mineral. Sekitar $68 \%$ responden menilai pengalaman sebelumnya terhadap multivitamin mineral sebagai faktor yang mempengaruhi minat beli. Faktor lainnya yang diduga dapat mempengaruhi minat beli konsumen adalah faktor harga (60\%), rekomendasi keluarga (56\%), rekomendasi teman (44\%), rekomendasi apoteker/dokter (28\%), dan promosi dalam toko/apotek (14\%). Hal tersebut memberikan asumsi bahwa responden yang sudah pernah mengonsumsi suatu produk multivitamin mineral akan cenderung untuk membeli produk yang sama. Sesuai hasil studi pendahuluan, iklan produk hanya menjadi faktor kelima yang dianggap dapat mempengaruhi minat beli produk multivitamin mineral. Untuk keperluan promosi dan pemasaran, dapat pula dipertimbangkan hal lain seperti edukasi pada apoteker/ dokter agar dapat memberikan rekomendasi produk (personal selling), edukasi singkat pada konsumen agar dapat lebih memahami produk dan juga memiliki keinginan untuk mencoba produk, atau promosi dari sisi harga seperti penurunan harga dan promosi dalam toko.

\section{PENUTUP}

Berdasarkan hasil penelitian, uraian dan pembahasan dalam bab-bab sebelumnya, temuan utama yang dapat disimpulkan adalah sebagai berikut.

1. Pesan iklan, keterlibatan iklan, kredibilitas endorser, dan kecocokan endorser berpengaruh positif pada sikap terhadap iklan Pharmaton ${ }^{\circledR}$ Formula.

2. Pesan iklan, keterlibatan iklan, kredibilitas endorser, dan kecocokan endorser berpengaruh positif pada sikap terhadap merek Pharmaton ${ }^{\circledR}$ Formula.

3. Sikap terhadap iklan Pharmaton ${ }^{\circledR}$ Formula berpengaruh positif pada sikap terhadap merekPharmaton ${ }^{\circledR}$ Formula. 
4. Sikap terhadap iklan dan sikap terhadap merek berpengaruh positif pada minat beli produk Pharmaton ${ }^{\circledR}$ Formula.

Temuan dari hasil penelitian ini adalah sikap terhadap iklan dan merek mempengaruhi minat beli konsumen untuk produk Pharmaton ${ }^{\circledR}$ Formula. Namun, pengaruh yang diberikan relatif kecil sehingga terdapat faktor lain yang mempengaruhi minat beli. Peneliti menyarankan agar penelitian selanjutnya dapat mengembangkan hasil penelitian ini terutama pada pengamatan terhadap faktor lain yang mempengaruhi minat beli seperti harga, rekomendasi teman/ keluarga/ dokter/ apoteker, pengalaman sebelumnya, promosi dalam toko, dan lain-lain. Untuk penelitian berikutnya yang ingin dilakukan mirip dengan penelitian ini, peneliti menyarankan agar menggunakan responden yang lebih luas dalam konteks mencakup kota-kota besar di Indonesia seperti Jakarta, Bandung, Surabaya, dan lain-lain. Responden penelitian yang lebih luas diharapkan dapat mewakili penduduk Indonesia secara umum sehingga menghasilkan temuan yang lebih komprehensif.

\section{DAFTAR PUSTAKA}

Aziz, S., U. Ghani, and A. Niazi. 2013. Impact of celebrity credibility on advertising effectiveness. Pakistan Journal of Commerce and

Biswas, D., A. Biswas, and N. Das. 2006. The differential effects of celebrity and expert endorsements on consumer risk perceptions. the role of consumer knowledge, perceived congruency, and product technology orientation. Journal of Advertising. 35(2). 17-31.

Buda, R., andY. Zhang. 2000. Consumer product evaluation: the interactive effect of message framing, presentation order, and source credibility. Journal of Product \& Brand Management. 9(4). 229-242.

Burhanudin, T. 2014. Segmen Menengah dan Bawah Dorong Industri Farmasi. http://www.marketing.co.id/segmenmenengah-dan-bawah-dorong-industrifarmasi/. Diakses tanggal 21 Oktober 2014.
Choi, SM., and NJ. Rifon. 2012. It Is a Match: The impact of congruence between celebrity image and consumer ideal self on endorsement effectiveness. Psychology and Marketing. 29(9). 639-650.

Friedman, HH., andL.Friedman. 1979. Endorser effectiveness by product type. Journal of Advertising Research. 19(5). 63-71.

Ghozali, I., dan Fuad. 2005. Structural Equation Modeling: Teori, Konsep, dan Aplikasi dengan Program LISREL 8.50. Semarang. Badan Penerbit Universitas Diponegoro.

Hair, JF., RP. Bush, and DJ. Ortinau. 2003. Marketing Research-Within A Changing Information Environment. $2^{\text {nd }}$ ed. New York. McGraw Hill Irwin.

Hemamalini, KS., and SK. Kurup. 2014. Effectiveness of television advertisement on purchase intention. International Journal of Innovative Research in Science, Engineering and Technology. 3(2). 9416-9422.

Jaccard, J. and CK. Wan. 1996. LISREL Approaches to Interaction Effects in Multiple Regression. Thousand Oaks. CA: Sage Publications.

Khatri, P. 2006. Celebrity endorsement: a strategic promotion perspective. Indian Media Studies Journal. 1(1). 25-37.

Ladha, Z. 2007. Marketing strategy: are consumers really influenced by brands when purchasing pharmaceutical products? Journal of Medical Marketing. 7(2). 146 - 151.

MacKenzie, Scott B and Ricard J.Lutz .1989, An empirical examination of the stratural antecedents of attitude toward ads in an advertising pretesting context, Journal of Marketing Research, 23 May, pp. 130-143.

Maheswaran, D.,and J. Meyers-Levy. 1990. The influence of message framing and issue involvement. Journal of Marketing Research. 27: 361-367.

Mehta, A. 1994. How Advertising Response Modeling (ARM) can increase ad 
effectiveness. Journal of Advertising Research. May/June. 62-74.

Nielsen Global AdView. 2013. Global AdView Pulse Lite Your Connection To Global Advertising Trends Quarter 32013. The Nielsen Company. http://www.cciag.ch/wp-content/uploads/globaladview-pulse-2013-q3-lite.pdf. Diakses tanggal 21 Oktober 2014.

Ohanian, R. 1990. Construction and validation of a scale to measure celebrity endorsers' perceived expertise, trustworthiness, and attractiveness. Journal of Advertising. 19(3). 39-52.

Petty, RE., JT. Cacioppo, and D. Schumann. 1983. Central and peripheral routes to advertising effectiveness: the moderating role of involvement. Journal of Consumer Research. 10. 135-146.

Schermelleh-Engel, K., H. Moosbrugger, and H. Müller. 2003. Evaluating the fit of structural equation models: tests of significance and descriptive goodnessof-fit measures. Methods of Psychological Research Online. 8(2). 23-74.

Schumacker, RE., and RG. Lomax. 2010. A Beginner's Guide To Structural Equation Modeling. $3^{\text {rd }}$ ed. New York. Routledge Taylor \& Francis Group.

Solomon, MR. 2008. Consumer Behavior: Buying, Having, and Being. 8th ed. Harlow. Pearson.

Wang, JS., YF. Cheng, and YL.Chu. 2013. Effect of Celebrity Endorsements on Consumer Purchase Intentions: Advertising Effect and Advertising Appeal as Mediators. Human Factors and Ergonomics in Manufacturing \& Service Industries. 23(5). 357-367.

Yi, Y. 1990. Cognitive and Affective Priming Effects in The Context for Print Advertisement. Journal of Advertising. 19(2). 40-48.

Zafar, QUA., and M. Rafique. 2012. Impact of celebrity advertisement on customers' brand perception and purchase intention. Asian Journal of Business and Management Sciences. 1(11). 5367.

Wangsa, G. C. U., \& Ardani, I. G. A. K. S. 2015. Peran sikap pada iklan dalam memediasi pengaruh kredibilitas al ghazali sebagai endorser terhadap niat beli (Studi Pada Produk Men's Biore Cool Oil Clear Di Kota Denpasar). EJurnal Manajemen Universitas Udayana, 4(3).538-337

Dominanto, N. N. 2008. Perbedaan sikap terhadap iklan, merek, dan niat beli konsumen pada iklan dengan fear appeal tinggi dan rendah pada partisipan wanita. Ekonomi \& Bisnis, 2(2), 67-75.

Biehal, G., Stephens, D., \& Curio, E. 1992. Attitude toward the ad and brand choice. Journal of Advertising, 21(3), 19-36.

Bosnjak, M., Obermeier, D., \& Tuten, T. L. 2006. Predicting and explaining the propensity to bid in online auctions: a comparison of two action-theoretical models. Journal of Consumer Behaviour, 5(2), 102-116.

Stafford, M. R., Stafford, T. F., \& Day, E.2002. A contingency approach: The effects of spokesperson type and service type on service advertising perceptions. Journal of Advertising, 31(2), 17-35.

Stephanie, E. 2013. Pengaruh kredibilitas endorser terhadap minat beli melalui sikap atas iklan pada produk shampo l'oreal di Surabaya. Calyptra: Jurnal Ilmiah Mahasiswa Universitas Surabaya, 2(2).

Goldsmith, R. E., Lafferty, B. A., \& Newell, S. J. 2000. The impact of corporate credibility and celebrity credibility on consumer reaction to advertisements and brands. Journal of Advertising, 29(3), 43-54.

Ishak, A. 2008. Pengaruh penggunaan selebritas dalam iklan terhadap minat beli konsumen. Jurnal Siasat Bisnis, 12(2). 
Lafferty, B. A., \& Goldsmith, R. E. 1999. Corporate credibility's role in consumers' attitudes and purchase intentions when a high versus a low credibility endorser is used in the ad. Journal of business research, 44(2), 109-116.
Erdogan, B. Z. 1999. Celebrity endorsement: A literature review. Journal of marketing management, 15(4), 291-314.

Rex, M. 1997. Source expertise and attractiveness of celebrity endorsers: a literature review. cyber Journal of Sport Marketing, Issn, 1327-6816. 